DOI

\title{
ВИКОРИСТАННЯ МЕТОДИК СИМУЛЯЦИЙНОГО НАВЧАННЯ У ПІДВИЩЕННІ ПРОФЕСІЙНОЇ КОМПЕТЕНЦІЇ ЛІКАРІВ ТА ПАРАМЕДИКІВ НА КАФЕДРАХ ДЗ “ЗМАПО МОЗ УКРАЇНИ”
}

\author{
О. С. Никоненко, С. Д. Шаповал, С. М. Дмитрієва, Т. О. Грицун \\ ДЗ “Запорізька медична академія післядипломної освіти МОЗ України”

\section{USE OF SIMULATING TEACHING METHODS TO INCREASE EDUCATION AND PROFESSIONAL COMPETENCE OF DOCTORS AND PARAMEDICS AT THE STATE INSTITUTE “ZAPOROZHYE MEDICAL ACADEMY OF POSTGRADUATE EDUCATION, MINISTRY OF HEALTH OF UKRAINE”}

\author{
O. S. Nykonenko, S. D. Shapoval, S. M. Dmytriyeva, T. O. Hrytsun \\ State Institute "Zaporozhye Medical Academy of Postgraduate Education, \\ Ministry of Health of Ukraine”
}

\begin{abstract}
У статті представлено аналіз та роль симуляційних методик, впроваджених на кафедрах ДЗ “ЗМАПО МОЗ України”, та оцінку отриманих лікарями компетенцій за класифікацією Блума. Показано, що використання симуляційних методик дозволяє відтворити тісний зв'язок навчального процесу з практикою і максимальну реалістичність клінічної ситуації у післядипломній освіті лікарів.
\end{abstract}

The modeling techniques, which implemented in the postgraduate education of doctors, and evaluating of competency by Bloome classification were analyzed in this article. Conclusions about the role of use of simulation methods as the main part of relationship of the educational process and the real clinical practice in post-graduate education of physicians were made.

Вступ. Застосування сучасних технологій освоєння і вдосконалення практичних навичок у фаховій підготовці медичних працівників є важливою умовою для забезпечення їх якісної професійної компетенції. Симуляційна освіта широко використовується в практичній підготовці медичних фахівців у розвинених країнах. Відпрацювання навичок на роботах-симуляторах та у віртуальних операційних має доведену ефективність як в Україні, так і за кордоном [1-3]. Саме завдяки таким технічним засобам навчання створюються необхідні умови для освоєння і закріплення практичних навичок, коли їх відпрацювання максимально наближено до реальної діяльності фахівців. Багато практикуючих лікарів підтверджують, що їм бракує впевненості в ургентних ситуаціях, тому, звичайно, потрібні нові підходи для поліпшення їх технічних, вербальних навичок та нави- чок роботи у команді (мультидисциплінарний та мультипрофесійний підхід).

Сьогодні перспективним шляхом удосконалення системи медичної освіти України є створення та розвиток симуляційних центрів заради підвищення професійного рівня лікарів та парамедиків. Крім того, застосування симуляційних моделей та фантомів у навчанні лікарів загальної практики - сімейної медицини задовольнять потреби досягнення певних компетенцій, до яких відноситься надання невідкладної допомоги та навчання взаємодопомоги своїх пацієнтів та членів їх родин [4].

Основна частина. У ДЗ “ЗМАПО МОЗ України” технології симуляційного навчання використовуються при навчанні лікарів-курсантів, інтернів та парамедиків на практичних заняттях, тренінгах та майстер-класах, відтворюються клінічні ситуації відповідно до мети навчання.

( О. С. Никоненко, С. Д. Шаповал, С. М. Дмитрієва, Т. О. Грицун 
Симуляційна форма навчання $є$ найбільш оптимальною при наданні екстреної та невідкладної медичної і домедичної допомоги, зокрема, в умовах бойових дій. Саме в цьому випадку можливо більш повно і реалістично моделювати об’єкт у певній ситуації, отримати необхідні теоретичні та практичні знання, відпрацьовувати конкретні навички, не завдаючи шкоди здоров’ю людини. Особливо гостро це питання стоїть для лікарів невідкладних станів та парамедиків.

На базі кафедри медицини невідкладних станів ДЗ “ЗМАПО МОЗ України”, навчальнотренувальному відділенні КУ “ТМО “ОЦЕМД та МК” 3ОР, використовуються такі форми симуляційного навчання:

- бригадна форма навчання (лікар, фельдшер, молодша медсестра і водій ШМД) алгоритму спеціалізованої серцево-легеневої реанімації;

- проведення майстер-класу з питань сортування при невідкладних станах;

- проведення майстер-класу з надання екстреної допомоги при утопленні, політравмі, сторонніх тілах верхніх дихальних шляхів;

- проведення майстер-класу з надання екстреної допомоги при бойовій травмі для саніструкторів і бійців Української армії та волонтерів;

- проведення семінарів-тренінгів з учнями загальноосвітніх шкіл і ліцеїв.

У навчанні використовуються манекени Little AnneTM, Crash KellyTM, Laerdal airway management TrainerTM, Deluxe difficult airway TrainerTM (Laerdal); апаратура з оснащення бригад ШМД (дефібрилятор-монітор від Philips; пульсоксиметр; супраглоткові повітроводи; мішок “Ambu”; транспортні дошки; пневмошини; КЕД-системи).

Міждисциплінарні тренінги та майстер-класи, що організовані кафедрою медицини невідкладних станів, надають можливість одночасного залучення в процес медичних працівників різних спеціальностей (акушер-гінеколог, неонатолог, медична сестра; лікар швидкої допомоги, медична сестра; хірурги, анестезіолог, медична сестра тощо).

Тренінги такого формату допомагають:

- відпрацювати алгоритм дій у конкретній клінічній ситуації;

- оптимізувати командну роботу;

- вдосконалити роботу лікарів та середнього медичного персоналу;

- чітко розподіляти обов’язки в команді.
3 метою поліпшення ефективності надання домедичної та першої медичної допомоги постраждалим з травмою та бойовою травмою на базі ДЗ “ЗМАПО МОЗ України” проводяться заняття 3 лікарями-інтернами за програмою "Основи підтримки життєдіяльності в умовах бойових дій”.

На тренінгах з надання домедичної та першої медичної допомоги умовно постраждалим з травмою та бойовою травмою лікарі-інтерни відтворюють реалістичну клінічну ситуацію, відпрацьовують на муляжах практичні навички “тактичної медицини":

- тимчасова зупинка зовнішньої кровотечі з використанням джгута САТ;

- відновлення прохідності дихальних шляхів;

- надання допомоги при дихальному напруженому пневмотораксі;

- серцево-легенева реанімація.

Викладення теоретичного матеріалу відбувається диференційно (короткі лекції-презентації, пов’ язані з конкретними ситуаціями та практичними моментами). Наприкінці лікарі-інтерни складають тестовий контроль знань.

Практична підготовка лікарів-інтернів під час тренінгу з екстреної медичної допомоги відбувається поетапно:

1. Визначення рівня володіння клінічними навичками на початку практичного заняття.

2. Навчання роботи на муляжах (ознайомлення 3 манекеном та обладнанням, демонстрація клінічних навичок викладачем, пояснення).

3. Індивідуальне виконання інтернами (відпрацювання).

4. Перевірка викладачем рівня освоєння практичних навичок (обговорення, оцінка).

5. Робота в команді (інсценування, міждисциплінарні тренінги).

6. Дебрифінг (оцінка динаміки групової роботи, самооцінка).

В ході психологічного дебрифінгу відбувається детальний аналіз та оцінка роботи лікарського персоналу, розробляється єдиний алгоритм дій згідно 3 клінічними стандартами [5].

Таким чином, при симуляційному навчанні враховуються всі три аспекти класифікації Блума 3 оцінки цільових навчальних компетенцій:

- когнітивні завдання навчання (знання) - “Що учасники програми мають знати?”;

- психомоторні завдання навчання (вміння) - “Що учасники мають вміти робити?”; 
- афективні завдання навчання (поведінка) - “Про що учасники мають думати або піклуватись?” [3].

Симуляційне навчання запроваджено також на інших кафедрах ДЗ “ЗМАПО МОЗ України”.

Тренінги з застосуванням симуляційних методик характеризуються низкою безперечних переваг у порівнянні із традиційними методами навчання [4]. На кафедрах акушерства і гінекології та загальної практики - сімейної медицини з курсами дерматовенерології та психіатрії створені всі умови, які дозволяють максимально ефективно і досконало оволодіти знаннями, а також відпрацювати основні професійні навички сімейних лікарів. Для лікарів загальної практики - сімейної медицини та фахівців в області репродуктивного здоров’я в практичному навчанні використовуються муляжі поперечного розрізу матки для демонстрації навиків введення та видалення ВМС, гінекологічний муляж ZOE, муляж молочної залози.

На тренінгу “Хірургічний гемостаз при масивних акушерських кровотечах” на клінічному муляжі учасники відпрацьовують навички хірургічного гемостазу - перев’язку маткової, яєчникової і внутрішньої клубової артерії. Також на кафедрі акушерства та гінекології використовується муляж для освоєння практичних навичок щодо виправлення дистоції плічок плода під час пологів.

Викладачі кафедри травматології та ортопедії використовують муляжі для оцінки практичних навиків з внутрішньосуглобових ін'єкцій; локальної терапії глюкокортикоїдами фасциітів, епікондилітів; проведення різноманітних блокад.

На кафедрі хірургії і проктології, під час практичних майстер-класів для лікарів-інтернів, використовується драйбокс з інструментами для відпрацювання навиків накладення лапароскопічного шва.

Оволодіння клінічними навичками за допомогою манекенів, тренажерів під наглядом викладача дає можливість інтернам і курсантам робити “безпечні” помилки, досягаючи таким чином вищого рівня клінічної компетентності.

Навчання за допомогою комп’ютерних симуляційних програм передбачає розвиток клінічного мислення в будь-якій медичній спеціальності. На кафедрі очних хвороб ДЗ “ЗМАПО МОЗ України” під час практичних занять та самостійної роботи слухачів використовуються комп’ютерні симулятори по анатомії ока та симулятори зорових функцій при різних патологіях зору (MSD Ophthalmics). Око можна розглянути в різних зрізах одним кла- цанням комп’ютерної мишки: отримати дані про будь-яку структуру при наведенні. Зображення на екрані може бути легко збільшено, зменшено, показано в тривимірному зображенні, що більш чітко допомагає оцінити структури і їх співвідношення. Анатомічні зрізи ока передають реальне зображення об’єкта, зберігаючи їх пропорції і просторовий розмір у точному вигляді. Комп’ютерні програми, які імітують різноманітні патологічні стани та їх прогресію, допомагають зіставити зорові порушення з тією чи іншою патологією.

Реалістична комп’ютерна симуляція допомагає набути певних навичок при меншому ризику і вартості - протягом одного дня можуть бути проведені сотні операцій з приводу катаракти або вітреоретинальної патології, не піддаючи пацієнта ризику. Крім того, симуляція забезпечує об’єктивну оцінку результатів навчання, провести сертифікацію [6].

Для опанування методу ехокардіографії на кафедрі кардіології ДЗ “ЗМАПО МОЗ України” застосовується комп’ютерна тривимірна модель Virtual transthoracic echocardiography, що розроблена у відділенні анестезіології госпіталю м. Торонто (Канада). Оскільки інтерфейс не дозволяє користувачеві фактично виконувати обрану дію або процедуру, цей симулятор у першу чергу сфокусований на когнітивному аспекті. Це дозволяє курсанту швидко засвоювати та візуально “впізнавати” зображення стандартних ехокардіографічних зрізів 3 урахуванням основних анатомічних маркерів. Він дає можливість вивчити всі 20 стандартних позицій, що використовуються при повному кардіологічному обстеженні, а також одночасно побачити відповідні цій позиції тривимірні моделі датчика, ультразвукової площини, серця та грудної клітки 3 можливістю перегляду під будь-яким кутом. Таким чином, дана тривимірна модель може застосовуватись викладачами для навчання великих груп лікарів та самоосвіти [7].

На кафедрі сімейної медицини та гастроентерології слухачам демонструється відеофільм “Дифференциальная диагностика НЯК и болезни Крона” 3 використанням відеоендоскопічного симулятора, призначеного для індивідуального виконання лікарем практичних навичок. На даний час у Д3 “ЗМАПО МОЗ України” проводиться робота зі створення навчально-тренінгового класу на основній навчальній базі академії.

Висновки: 1. Використання симуляційних технологій підвищує інтерес до процесу навчання i 
є важливою частиною в підвищенні професійної компетенції лікарів.

2. Комплексне оцінювання компетенції викладачем згідно з класифікацією Блума є важливим моментом у забезпеченні більш цілісного підходу до навчання.

\section{Список літератури}

1. National Growth in Simulation Training within Emergency Medicine Residency Programs / Y. Okuda [et al.] // Acad. Em. Med. - 2008. - № 15. - P. 1-4.

2. Симуляционное обучение в медицине / под ред. проф. А. А. Свистунова ; сост. М. Д. Горшков. - М. : Издательство Первого МГМУ им. И. М. Сеченова, 2013. - 288 c.

3. Створення симуляційного центру: засади та керівні настанови. Досвід Програми “Здоров’я матері та дитини” : посібник. - К. : Вістка, 2015. - 56 с.

4. Роль симуляційних методів навчання на післядипломному етапі медичної освіти лікарів загальної практики - сімейних лікарів / О. Г. Шекера, Л. Ф. Матюха, Н. В. Малютіна [та ін.] // Збірник наукових праць співробітників НМАПО ім. П. Л. Шупика. - 2014. Вип. 23 (1). - С. 643-647.
3. Актуальним залишається питання щодо розповсюдження досвіду використання симуляційних методик у післядипломній освіті та безперервному професійному розвитку лікарів.

5. Льовкін О. А. Досвід використання симуляційних технологій під час навчання лікарів і парамедиків у місті Запоріжжя / О. А. Льовкін, К. В. Серіков, К. К. Малашенко // Екстрена медицина від науки до практики. - 2015. - № 3. - С. 22-29.

6. Использование компьютерных симуляторов в самостоятельной работе врачей интернов и курсантов на кафедре офтальмологии / Н. Г. Завгородняя, О. А. Рудычева, Н. С. Луценко [и др.] // Матеріали VII навч.-метод. конф. ДЗ “ЗМАПО МОЗ України”. - Запоріжжя, 2010. - С. 31-32.

7. Використання екранних симуляторів з метою опанування методу трансторакальної ехокардіографії / М. Я. Доценко, С. С. Боєв, І. О. Шехунова [та ін.] // Матеріали ХІІ навч.-метод. конф. ДЗ “ЗМАПО МОЗ України”. - Запоріжжя, 2015. - С. 39-40. 